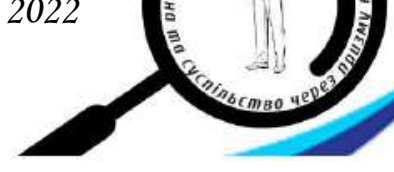

УДК 37.018.43:37.012:004(045)

https://doi.org/10.52058/2786-5274-2022-1(3)-283-291

Розман Ірина Іллівна кандидат педагогічних наук, доцент, доцент кафедри англійської мови, літератури з методиками навчання, Мукачівський державний університет, вул. Ужгородска, 26, м. Мукачево, 89600, тел.: (03131) 211-09, https://orcid.org/0000-0002-4951-0074

\title{
ДИСТАНЦІЙНЕ НАВЧАННЯ: НАСЛІДКИ ТА ОСВІТНІ ТЕХНОЛОГІЇ
}

Анотація. У статті йдеться про наслідки Covid-19 у системі освіти, про те, що пандемія значною мірою серйозно змінила підхід на навчання, внесла корективи до визначення чіткості та своєчасного зворотного зв'язку 3 викладачами та здобувачами освіти. Зазначено, що нововведення, які пов'язані зі зміною викладання дисциплін стали неочікуваними та недостатньо опрацьованими.

Закцентована увага, що у вже сталому традиційному навчанні виникає нова інформація, 3 якою світ ніколи не зустрічався в таких масштабних викликах i, практично, всі галузі економіки, соціально-політичного життя в екстремальних умовах почали перебудовувати свою діяльність. Зауважено, що під час кризи та адаптації до сучасних умов, стало успішне проведення онлайн-занять у Teams або Zoom, які дозволили працювати у форматі питання - відповіді.

Зауважено, що робота співробітників освітніх установ скоріше знайшла зону комфорту у спілкуванні, а зв'язок зі здобувачами на перших стадіях був дещо складним у силу суб'єктивних причин.

Наголошено що, у той час, коли все більше і більше людей дізнаються як на офіційних курсах, так i в повсякденному житті про опосередковані технології навчання, найбільш повні варіанти педагогічного дизайну при проектуванні онлайн-курсу відображені у Learning Online Barbara Means, Marianne Bakia and Robert Murphy, Learning Online: What Research Tells Us about Whether, When and How.

Висвітлено недоліки, які супроводжували онлайн-навчання: брак живого спілкування; призупинення студентських практик, так як вузи закриті на карантин; відсутність якісного зв’язку для роботи на онлайн-платформах; неапробовані програми для навчання у незвичних умовах; відсутність мотивації до навчання; перевантаженість Інтернет-мережі.

Наголошено, що чимало компаній працюють над тим, щоб забезпечити повноцінну менторську підтримку для студентів навіть за таких умов.

Ключові слова: дистанційне навчання, Covid-19, онлайн-навчання, наслідки, сучасні технології, IT-інфраструктура. 
Rozman Irina Illivna Candidate of Pedagogical Sciences, Associate Professor, Associate Professor of the Department of English language, literature with teaching methods of Mukachevo State University, 26 Uzhhorodskaya St., Mukachevo, 89600, tel.: (03131) 211-09, https://orcid.org/0000-0002-4951-0074

\section{DISTANCE LEARNING: IMPLICATIONS AND EDUCATIONAL TECHNOLOGIES}

Abstract. The article discusses the impact of Covid-19 on the education system, that the pandemic has significantly changed the approach to learning, and made adjustments to the clarity and timeliness of feedback from teachers and learners. It is noted that innovations related to changes in the teaching of disciplines have become unexpected and insufficiently developed.

Attention is focused on the fact that uncertainties in the already established traditional education are caused by the fact that the world has never faced such a large-scale challenge and, almost all sectors of the economy, socio-political life in extreme conditions have begun to rebuild their activities. It is noted that during the crisis and adaptation to modern conditions, it was possible to successfully conduct online classes in Teams or Zoom, which allowed us to work in the question-answer format.

It is noted that the work of employees of educational institutions rather found a comfort zone in communication, and communication with applicants at the first stages was somewhat difficult due to subjective reasons. It is noted that at a time when more and more people are learning about mediated learning technologies both in official courses and in everyday life, the most complete variants of pedagogical design when designing an online course are reflected in Learning online Barbara Means, Marianne Bakia and Robert Murphy, Learning Online: What Research Tells us about Whether, When and how.

The article highlights the shortcomings that accompanied online learning: lack of live communication; suspension of student practices, as universities are closed for quarantine; lack of high-quality communication to work on online platforms; untested programs for learning in unusual conditions; lack of motivation to study; reloading of the Internet network.

It is noted that many companies are working to provide full-fledged mentoring support for students even in such conditions.

Keywords: distance learning, Covid-19, online learning, consequences, modern technologies, IT infrastructure.

Постановка проблеми. За даними ООН пандемія Covid-19 призвела до найбільшого за всю історію збою у функціонуванні систем освіти, який торкнувся майже 1,6 мільярда учнів у більш ніж 190 країнах i на всіх континентах. Закриття шкіл та інших освітніх установ торкнулося $94 \%$ 
світового контингенту здобувачів, причому у країнах з низьким рівнем доходу і з рівнем доходу нижче середнього цей показник становить $99 \%$.

Криза посилила сьогоденні і вже раніше існуючі проблеми нерівності у сфері освіти, які змушують значній частині людей знаходитися у важких умовах існування. Найбільш постраждали ті верстви населення, які живуть у бідних або сільських районах; біженці, інваліди та насильно переміщені особи. Їм надзвичайно важко продовжувати навчання. Крім того, освітні втрати загрожують охопити i майбутні покоління, ліквідуючи досягнення багатолітнього прогресу, що не в останню чергу стосується сприянню гендерної політики: доступу жінок до освіти і продовження навчання.

Якщо говорити тільки про економічні наслідки пандемії, то ще близько 23,8 мільйона дітей від дошкільнят до здобувачів вищої освіти можуть наступного року кинути навчання або опинитися без доступу до неї [6].

Аналіз останніх досліджень і публікацій. Про вплив кризи, викликаної пандемією COVID-19 у сфері науки освіти і науки висвітлюють у своїх наукових публікаціях вчені Горват, Д., Мітев, А., та Бауер, А. Бондаренко С. Ю., Биковська, I. В., Рибалка В. В.

Мета статті полягає у висвітленні вимог щодо використання дистанційного навчання та ознайомлення 3 умовами використання освітніх технологій у період коронавірусної пандемії.

Виклад основного матеріалу. Для результативної роботи необхідно представити дорожню карту дій. Правильно спланована і організована робота завжди дає позитивний результат. У нашому випадку сучасні технології відіграють ключову роль у дистанційному навчанні. Розглянемо, за допомогою яких технологій здійснюється дистанційне навчання. Нам всім добре відомі освітні візуальні засоби, які включають в собі статичні зображення (наприклад, слайди), заздалегідь створені рухомі картини (кінофільми, відео фільми і т.д.), а також відео-зображення в поєднанні з аудіо-конференціями.

3 весни 2019 року викладачі почали інтенсивно використовувати електронні освітні засоби, головним чином, комп'ютери, за допомогою яких пересилають і отримують інформацію за допомогою електронних технологій. Комп'ютерні програми для дистанційного навчання можуть бути самими різними: електронна пошта, факс, комп'ютерні конференції в реальному часі, а також WWW - додатки.

У розпорядженні викладачів, які працюють дистанційно, знаходяться найрізноманітніші технічні засоби. Вони включають в собі освітні візуальні засоби, освітні аудіо-засоби, освітні електронні засоби i, нарешті, традиційні освітні друковані засоби.

Звукові або аудіо-засоби - телефонний зв'язок, аудіо-конференції. Друковані освітні засоби - фундаментальна складова дистанційної освіти, на базі якої утворилися всі інші системи передачі інформації. Вони включають в себе підручники, путівники, робочі зошити, навчальні курси і т.д. Оскільки 
друковані засоби не вимагають спеціальних навичок і оточення для роботи 3 ними, а також є самим недорогим 3 усіх перерахованих вище засобів, їм віддається перевага і в дистанційному освітньому процесі. Однак, як викладачі, так і здобувачі почали використовувати електронні книги, підручники, довідники, інформаційні довідки все частіше у своїй роботі.

Хоча технологія відіграє ключову роль у проведенні дистанційної освіти, викладачі, працюючи дистанційно, повинні зосередитись головним чином на результатах дистанційної освіти, а не на самих технологіях.

Ключем до успішного вибору технологій дистанційної освіти є вміння приділити основну увагу вимогам та критеріям для здобувачів; вимогам, що пред’являються до змісту навчання; необхідно звернути увагу на труднощі, 3 якими стикається викладач. Зазвичай мета досягається у випадку застосування відразу декількох інформаційних засобів, кожне з яких служить певній меті. При цьому слід прагнути до максимальної ефективності навчання, яке, в той же час, повинно бути вигідним i iз економічної точки зору.

Необхідно зазначити, що з введенням онлайн-навчання, більшу частину часу здобувачі приділяють самоосвіті. Для викладача важливішим $є$ рівень знань, які були опановані студентами, а не тільки види дистанційного викладу матеріалу. Як результат, найпопулярнішими технологіями навчання $\epsilon$ електронні контрольні тести, електронні підручники та навчальні програми. Для практичних занять використовуються друковані видання-підручники та робочі зошити для самостійної роботи студентів. При підготовці індивідуальних завдань учні використовують Інтернет-технології та мультимедійні технології. Крім перерахованого вище, в процесі самостійної підготовки i, безпосередньо на заняттях, застосовуються аудіо-записи та відеофільми. На жаль, через високу вартість і поки недостатню технічну оснащеність, на даний момент залишається неможливим якісно використовувати в процесі навчання відео-конференції, що набувають все більшої популярності при навчанні дистанційно.

Більше того, зрив освітнього процесу має і буде мати серйозні наслідки за рамками системи освіти. Закриття закладів навчання та виховання ускладнює надання важливих послуг дітям та громадам, включаючи організацію повноцінного харчування, що позначиться на здібності багатьох батьків виконувати свою роботу і сприятиме зростанню ризику насильства.

У той же час не можна не відзначити, що криза послужила стимулом для інновацій у сфері освіти. Задля забезпечення безперервності навчання численні дослідження в галузі освітніх технологій сходяться в тому, що в основі онлайннавчання лежить ретельно спроектований і спланований навчальний процес.

Підтримуваний методично-обгрунтованою i цілеспрямованою послідовністю навчально-методичних матеріалів, які забезпечують досягнення результатів навчання у форматі виключно електронного навчання, дає можливість організувати освітній процес, який уможливлює зосередитись на 
здобутті нових знань.

Домінантом зазначеного питання є визначення педагогічного дизайну як інструменту планування проведення онлайн-курсів, які відсутні у більшості випадків при різкому переході на «дистанційку».

Пропонуємо звернути увагу на такі форми навчання, як чат-навчання (проводиться одночасно з усіма учасниками заняття). Зазначений захід має можливість перейти у чат-кабінет, чат-школу). Веб-заняття - дистанційні уроки, конференції, семінари, ділові ігри, лабораторні роботи, практикуми та інші форми навчальних занять, що проводяться за допомогою засобів телекомунікацій та інших можливостей Інтернету. Як результат, залишаються записи на одному із сайтів з встановленою на ньому відповідною програмою. Чат-заняття відрізняється від веб-заняття більш тривалою за часом (можлива багатоденною) роботою та неодночасною взаємодією викладача та здобувача. Використовуючи електронну пошту, встановлюється дедлайн для проведення телеконференції. Для них характерним $є$ досягнення освітніх завдань, де для закріплення залишаються посилання або відбувається розсилка по пошті у регіони. Такий метод навчання отримав назву «природний процес навчання» (Natural Learning Manner) [4].

У той час, коли все більше і більше людей дізнаються як на офіційних курсах, так і в повсякденному житті про опосередковані технології навчання, найбільш повні варіанти педагогічного дизайну при проектуванні онлайнкурсу відображені у Learning Online Barbara Means, Marianne Bakia and Robert Murphy, Learning Online: What Research Tells Us about Whether, When and How [1]. Автори пропонують нам основні характеристики, які необхідно враховувати при проектуванні курсу, з альтернативними варіантами реалізації онлайн-навчання: модель навчання, темп освоєння матеріалу, кількість здобувачів у групі, педагогічну технологію коучів, мету оцінювання на курсі, роль викладача та ціль слухача i, звичайно feedback, зворотній зв’язок.

Результативні та конкретні технології онлайн-навчання: масові відкриті онлайн-курси, ігри для кількох гравців, аналітика навчання та адаптивні онлайн-практики, описані 3 точки зору принципів дизайну, реалізації та контексту використання, - серйозна допомога при дистанційному навчанні.

Всі ці параметри є потужним впливом на організаційний дизайн онлайнкурсу на форми подання контенту, на вибір контрольно-узагальнюючих інструментів, на використання тих чи інших сервісів комунікації та проведення процедури підсумкової атестації з курсу.

Актуальність, доступність формальної, інформальної та неформальної освіти дає можливість здобути знання навіть і під час кризисних ситуацій, у нашому випадку Covid - 19.

Правильно підібрані матеріали для проведення курсу, виходячи з цілей і завдань навчання і характеристик навчального процесу в онлайн-середовищі, забезпечать освітній результат для здобувачів, а викладачеві надаватимуть 
позитивний зворотний зв’ язок.

Такий підхід передбачає, що онлайн-навчання - це, перш за все, когнітивний і соціальний процес, а не просто процес передачі інформації за допомогою Інтернет.

Так само, як i очне навчання, онлайн-навчання вимагає соціальної підтримки учнів. В очному навчанні цю роль виконують матеріальні ресурси вузу і викладачі, задіяні в навчальному процесі.

Онлайн-навчання неможливе без ІТ-інфраструктури, яка потребує значних інвестицій, включаючи платформу онлайн-навчання свою або зовнішню, 3 якою укладено договір, а також якісні онлайн-курси, що забезпечують ефективне навчання і підтримку учнів в онлайн-середовищі.

У нинішній ситуації, коли перехід на онлайн-навчання здійснюється в найкоротші терміни, всі ці умови повинні бути створені заздалегідь, а викладачі повинні мати досвід використання інструментів онлайн-навчання i сервіси підтримки здобувачів.

Практика показує, що на розробку онлайн-курсу йде в середньому півроку, а навички роботи викладача на онлайн-платформі формуються протягом перших двох запусків курсу.

Таким чином, неможливо очікувати високих та швидких результатів, навіть якщо самий просунутий в плані цифрових компетенцій викладач зробить все можливе для перенесення занять в онлайн-середу: запише кілька онлайн-лекцій, викладе текстові матеріали і завантажить тести на платформу дива не відбудеться.

Необхідно мати на увазі, що поняття «онлайн-навчання» відрізняється від тих занять, які потребують вкладення ресурсів i його можна назвати дистанційним навчанням в екстремальних умовах.

Для результативної роботи необхідно дотримуватись окремих вимогам до проведення онлайн-занять: надійність, пропускна здатність інтернет-каналів, простота створення і розміщення контенту, доступність сервісів і платформ для викладачів і учнів. Багато закладів вищої освіти вже більше десяти років користуються MOODL версією, яка допомагає студентам дистанційно опановувати аудиторні заняття та завдання для індивідуально-самостійного опрацювання.

3 високим ризиком зараження коронавірусом, вводиться дистанційна (іноді змішана) форма навчання. Велику популярність серед вузів мають LMSплатформи для розміщення контенту і перевірки знань студентів; вебінарні сервіси для онлайн-лекцій і консультацій, гостьові та бінарні лекції, соціальні мережі i месенджери для комунікації учнів i викладачів, розсилки по електронній пошті для доставки контенту [5].

Чимало вузів змогли скористатися безкоштовними онлайн-курсами від провідних провайдерів, що дозволяють в залежності від рівня інтернетпідготовленості опанувати зв'язок зі студентами. 


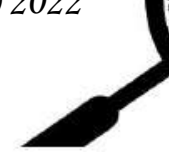

Однак навіть ці надані можливості не змогли забезпечити повноцінне освоєння студентами онлайн-курсів у зв'язку з тим, що безкоштовний доступ до контенту курсів не припускав підтримки учнів 3 боку вузів власників онлайн-курсів, а викладачі з боку університетів - споживачів не були занурені в контент курсу, не були знайомі 3 методикою онлайн-навчання і вивчали курси одночасно зі своїми студентами.

При цьому мотивовані, креативні як викладачі, так і студенти досить добре впоралися з поставленим завданням.

Закономірно, що викладачам не вистачило навичок роботи в цифровому середовищі, часу на освоєння нових інструментів і перебудову освітнього процесу та підтримки з боку технічних служб університету, які відіграють важливу роль при впровадженні нових технологій.

Навчання викладачів в настільки стислі терміни не представлялося можливим і звелося до інструктивних внутрішніх нарад, коротких вебінарів від експертного співтовариства, рекомендацій та інструкцій по роботі з різними сервісами і платформами, розміщеним на сайтах організацій.

Окремі відділи вузів піднімали питання щодо педагогічного дизайну та опрацювання проектів курсів. Нажаль, це відбувалось в наслідок форсмажорних обставин, які змусили вузи мобілізувати всі наявні ресурси і зробити ривок в масовому екстреному впровадженні дистанційних освітніх технологій, але не в планомірному використанні інструментів онлайн-навчання, що вимагає набагато більш тривалого часу [4].

ZOOM став, практично, платформою, яка замінила аудиторії, місця виробничих практик, стажувань, курсів підвищення кваліфікації та причиною виникнення онлайн-університетів.

Електронний контент, вирішує негайні потреби освітніх послуг, але їх слід відрізняти від повноцінних онлайн-курсів, які передбачають створення гнучкого інтерактивного студентоцентрованого онлайн-середовища для контрольованого освоєння знань і навичок.

I, як наслідок, немає підстав судити про ефективність онлайн-навчання за тими результатами, які будуть отримані в цьому «глобальному» експерименті екстреного переходу на дистанційне навчання.

Виникає велика спокуса щодо порівняння освітньої моделі навчання. Однак, без чітко-розроблених критеріїв суворого експериментального дизайну; ідентичного за змістом і різного за форматом контенту; однакових контрольноузагальнюючих матеріалів та умов проведення контрольних заходів та підсумкової атестації; технологій навчання; виключення впливу на результати експерименту зовнішніх факторів, що знижують валідність експерименту, неможливо бути впевненим у об'єктивному оцінюванні знать та якості тих самих знань.

При виникненні розуміння того, що $є$ результатом роботи як для викладача, так і для здобувача, крім успішності, велику роль відіграє мотивація 
і присутність студентів на занятті, їх залученість в процес навчання, вміння співпрацювати і досягати мети, поставленої перед собою.

Для адміністрації вузу на перший план виходять такі показники, як відсоток студентів, які завершили курс, скорочення навантаження викладачів $i$ підвищення продуктивності їх праці, охоплення ринку і обсяг залучених позабюджетних коштів [3].

Безумовно, особливому впливу піддалися оффлайн конференції і воркшопи - такі заходи, звичайно ж, максимально скоротилися. Але, наприклад, компанія Sigma Software знайшла вихід: щоб компенсувати цей період стагнації, для співробітників постійно готуються і оновлюються списки актуальних онлайн-курсів, книг і освітніх платформ, щоб фахівці навіть вдома могли підвищувати свою компетентність.

Серйозним мінусом стало призупинення студентських практик, так як вузи закриті на карантин. Але компанії працюють над тим, щоб забезпечити повноцінну менторську підтримку для студентів навіть за таких умов. На даний момент, всі основні освітні курси вже успішно переведені в онлайн режим незважаючи на те, що окремі формати були змінені. Так, наприклад, в нових реаліях IT компанії фокусуються більше на відносно коротких форматах - замість тренінгів, які можуть тривати від 6-8 годин до декількох днів, впроваджуються інтенсивні воркшопи/мітапи, які розраховані всього на кілька годин.

Що стосується таких заходів, для їх організації будуть зручними будь-які, навіть самі стандартні сервіси як Microsoft Teams або Skype (якщо кількість учасників не дуже велика). Якщо говорити про масштабні івенти-підійдуть Zoom, Gotowebinar, Mentimetr, ClickMeeting та інші [5].

У безкоштовних сервісах є ряд обмежень, тому слід перевіряти, що підійде у конкретному випадку і часі, все ж, краще не економити, а оформити повну, платну підписку і отримати максимально зручний для вас сервіс.

Протягом останніх півтора роки команда EPAM University Programs поступово переводила освітні програми в онлайн і blended-формати. Зокрема, курс Front-End online, який стартував близько двох років тому у Львові, вже минулого року успішно масштабувався на всю Україну. Освітні матеріали для онлайн-навчання розміщуються на платформах для дистанційного навчання, наприклад, Learn i Grow - це внутрішні інструменти компанії.

Обставини та ситуація навчання, які виникли з врахуванням пандемії, необхідно враховувати терміново і невідкладно. 3 цього випливає результат підтримки тих випускників, які, отримавши диплом про здобуття вищої освіти, не мають можливості працевлаштуватись і вдосконалювати свої теоретичні знання. Зникає можливість їх конкурентноспроможності на ринку праці. Відбуваються серйозні зміни, які пов'язані зі зміною шляхів та форм отримання професійних знань. У силу економічного становища батьки не в змозі оплатити навчання свої дітей і забезпечити їм майбутнє [5]. 


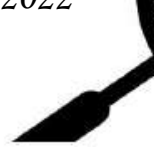

Саме тому виникає необхідність у співробітництві різного плану організацій для підтримки одне одного, у впровадженні інноваційних моделей співпраці. ЮНЕСКО пропонує створювати більше можливостей для інклюзивної освіти в період перерви в навчанні. Для розвитку відкритих, гнучких та актуальних систем навчання в періоди криз необхідно більше таких партнерств на національному та міжнародному рівнях. Хоча система ООН та інші міжнародні агентства можуть виступити в якості агрегатора, світу необхідно активне керівництво з боку держав для фінансування вищої освіти, а також участь приватного сектора в наймі випускників коледжів [6].

Щоб не допустити того, що криза освіти перетворилася у «кризу покоління», катастрофу, необхідні термінові дії з боку всіх суб'єктів.

Висновки. Отже, дистанційне навчання - це демократично-побудована система навчання яка $є$ водночас вільною. Освіта - це не просто одне 3 основних прав людини. Це основоположне право, від якого безпосередньо залежить реалізація всіх інших прав. Освіта - це загальне світове благо, найпотужніша рушійна сила прогресу в досягненні цілей в області сталого розвитку і складає основу для справедливого, рівноправного, інклюзивного та мирного суспільство. Коли системи освіти руйнуються, завдання побудови світу і процвітаючого і продуктивного суспільства стає нездійсненною.

\section{Лimepamypa}

1. Learning Online: What Research Tells Us About Whether. https://www.routledge.com».

2. Горват Д., Мітев А., Бауер А. Перемога медіа-стратегій у часи економічної кризи. Vezetéstudomány. Будапешт, 2014. C. 46-52.

3. Це не канікули: система дистанційного навчання. http://www.dut.edu.ua> news-1-5588104-karantin.

4. Дистанційне навчання: поняття та значенння. https://xreferat.com > 749

5. Освіта в епоху COVID-19 и в последующий период. https://www.un.org)sites> un2.un.org>.

6. ЮНЕСКО шукає стажера з питань освіти - Global Campaign. https://www.peace-edcampaign.org>unesco-seeks-edu.

\section{References:}

1.Learning Online: What Research Tells Us About Whether. Retrieved from https://www.routledge.com>. [in English].

2. Gorvat, D., Mitev, A., and Bauer A. (2014). Peremoha media-stratehii u chasy ekonomichnoi kryzy [Victory of media strategies in times of economic crisis]. Vezetéstudomány, 46-52. [In Ukrainian].

3.Tse ne kanikuly: systema dystantsiinoho navchannia na [It's not a vacation: a distance learning system]. Retrieved from http://www.dut.edu.ua > news-1-558-8104-karantin. [in Ukrainian].

4. Dystantsiine navchannia: poniattia ta znachennnia [Distance learning: concepts and meanings.] Retrieved from https://xreferat.com $>749$

5. Osvita v epokhu COVID-19 y v posleduiushchyi peryod [Sanctified in the era of COVID19 and beyond]. Retrieved from https://www.un.org >sites>un2.un.org>. [in Ukrainian].

6. YuNESKO shukaie stazhera z pytan osvity - Global Campaign [UNESCO is looking for an education intern]. Retrieved from https://www.peace-ed-campaign.org)unesco-seeks-edu. [in Ukrainian]. 